\title{
EXPERIMENTAL RESEARCH OF THE COAGULATION PROCESS OF EXHAUST GASES UNDER THE INFLUENCE OF ULTRASOUND
}

\author{
Adil Kadyrov, Bauyrzhan Sarsembekov, Aleksandr Ganyukov*, Zhanara Zhunusbekova, Kuanysh Alikarimov \\ Karaganda Technical University, Karaganda, Kazakhstan \\ *E-mail of corresponding author: ganukovktu@mail.ru
}

\section{Resume}

The authors propose the use of ultrasonic radiation to clean the exhaust gases of internal combustion engines of the solid particles. An experimental stand and research results are presented, proving the possibility and efficiency of using the process of ultrasonic cleaning of exhaust gases due to the process of the solid particles coagulation. The authors received a corresponding patent, the efficiency of which has been proven by results of the conducted research.

\section{Article info}

Received 22 February 2021

Accepted 8 March 2021

Online 27 August 2021

\section{Keywords:}

ultrasonic cleaning, ultrasonic muffler, exhaust gases, experiment, hydrodynamic coagulation, orthokinetic coagulation

ISSN 1335-4205 (print version) ISSN 2585-7878 (online version)

\section{Introduction}

One of the causes of air pollution is operation of a car engine. One of the main reasons for the excessive pollution by exhaust gases of our cities is the extremely low quality of automobile fuel. The exhaust gas consists of more than 170 harmful components, of which about 160 are hydrocarbon derivatives, which are the main causes of incomplete combustion of a fuel in an engine. The presence of harmful substances in the exhaust gases is ultimately determined by the type and condition of the fuel [1].

An increase in the concentration of exhaust gases leads to an increase in diseases of the cardiovascular system and lungs. Reducing the harmful emissions of exhaust gases from cars is an important task in solving the problem of environmental pollution [2].

The muffler is a part of the vehicle's exhaust system and is designed to reduce the noise level of a working internal combustion engine, reduce the temperature of exhaust gases and reduce the harmful emissions into the atmosphere. Reducing the harmful emissions in modern mufflers is carried out by installing systems for neutralizing and cleaning exhaust gases, operating on the methods of liquid, thermal, catalytic neutralization and particulate filters. Authors propose an ultrasonic method for cleaning the exhaust gases [3].

Currently, there are patents for ultrasonic cleaning of exhaust gases: when ultrasonic waves appear in a quarter-wave resonator, but without generating waves [4-6]. The article proves the advantage of cleaning exhaust gases using the design proposed in the patent [6].

In this research, the ultrasonic waves were generated by a generator. In addition, the process of cleaning the exhaust gases of a car differs in that the experimental muffler uses emitters of ultrasonic waves directed both in the transverse and longitudinal directions with respect to the exhaust gas flow.

\section{Hypothesis and purpose of the research}

The hypothesis is the assumed possibility of increasing the hydrodynamic coagulation of exhaust gases in the vehicle muffler under the action of ultrasonic waves. Coagulation refers to the adhesion and deposition of soot particles inside the muffler housing, which makes it possible to increase the efficiency of cleaning the exhaust gases from motor vehicles.

The aim of the research is to test the hypothesis of coagulation of soot particles under the action of ultrasonic exposure. To test the hypothesis, experimental modeling of the coagulation process was carried out on a specially designed stand and the physical essence of the process is described. 


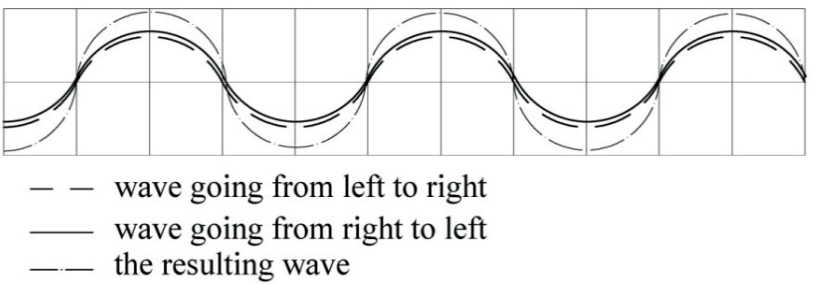

Figure 1 Formation of standing waves

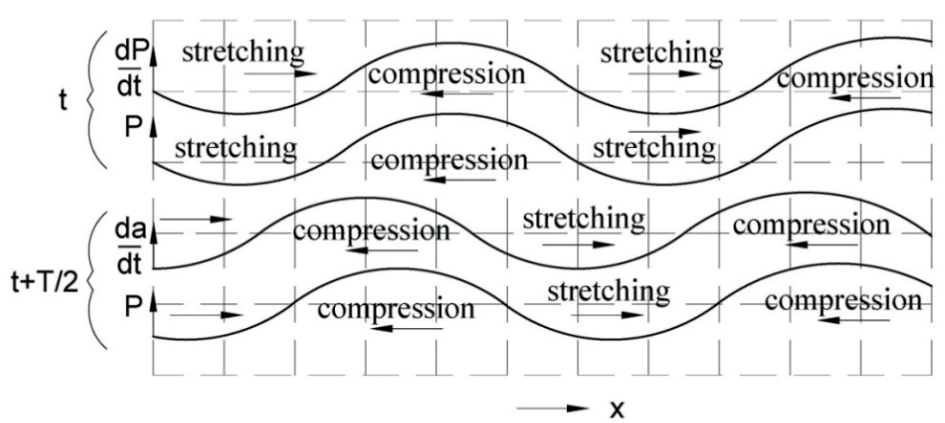

Figure 2 Velocity distribution $d a / d t$ and pressures $P$ in a standing sound wave

\section{The process of the gas particles coagulation under the action of ultrasound}

Coagulation is accelerated when exposed to ultrasound, which has a dispersing effect on emulsions and liquid sols and has a coagulating effect on aerosols (smoke, fog, dust). This is due to the fact that only longitudinal waves causing compression are possible in gases. Shear waves cause deformation shears. In a longitudinal wave, the particles of the medium oscillate about their mean position in the direction parallel to the wave propagation [7].

The efficiency of the coagulation process increases when a standing wave occurs. Standing waves are a special case of interference. In that case, the two identical waves propagate in opposite directions. Figure 1 shows a diagram of the emergence of standing waves [7].

The resulting oscillation (Figure 1) has the same wavelength but does not move in space (standing wave) through each half of the wave $(\lambda / 2)$, there are no oscillations (nodes); the antinode points are located in the middle.

The pressure $\mathrm{P}$ in a standing wave is proportional to the displacement and contains nodes and antinodes. In this case, the position of the pressure nodes coincides with the position of the antinode nodes and vice versa (Figure 2). The pressure amplitude is twice this value for a single wave.

For the gas particles of different sizes, a certain vibration frequency occurs. At first, the particles follow the movement of the gas between the antinodes and the nodes, while sticking together and increasing in size. After that, the particles increase due to chaotic oscillations. The exhaust gas is composed of particles of different sizes. Depending on their size and vibration frequency, particles can follow sound vibrations and coagulate [8].

This process takes place at low vibration frequencies. With an increase in the vibration frequency, there is an optimal frequency segment at which the particles of different sizes have different amplitudes, collide with each other and coagulate. This kind of coagulation is called orthokinetic. As the frequency increases, coagulation becomes hydrodynamic and is carried out by friction. This process is described by the Bjerknes equations [9].

However, the frequency value is limited by the degree of participation of gas particles in oscillations and in cases with a standing wave they are related to the particle radius $r$ and dynamic viscosity $\eta$.

The determining factor for the degree of participation of a particle in an oscillation is the quantity [9]

$Z=\frac{\rho r^{2} f}{\eta}$

where:

$Z$ - the particle magnification factor,

$\rho$ - particle density $\left[\mathrm{g} / \mathrm{m}^{3}\right]$,

$r$ - particle radius $[\mathrm{m}]$,

$f$ - frequency of gas oscillations under the action of ultrasound $[\mathrm{kHz}]$,

$\eta$ - dynamic viscosity [Pa.s].

Denoting in Equation (1) the moment of inertia of the particle as $I=\rho r^{2}$, we get:

$Z=\frac{I f}{\eta}$

Namely, the participation of a particle in vibrations is the greater, the greater its moment of inertia and the frequency of ultrasonic vibrations and less with increasing viscosity. Equation (2) is further considered as a necessary condition for coagulation. 


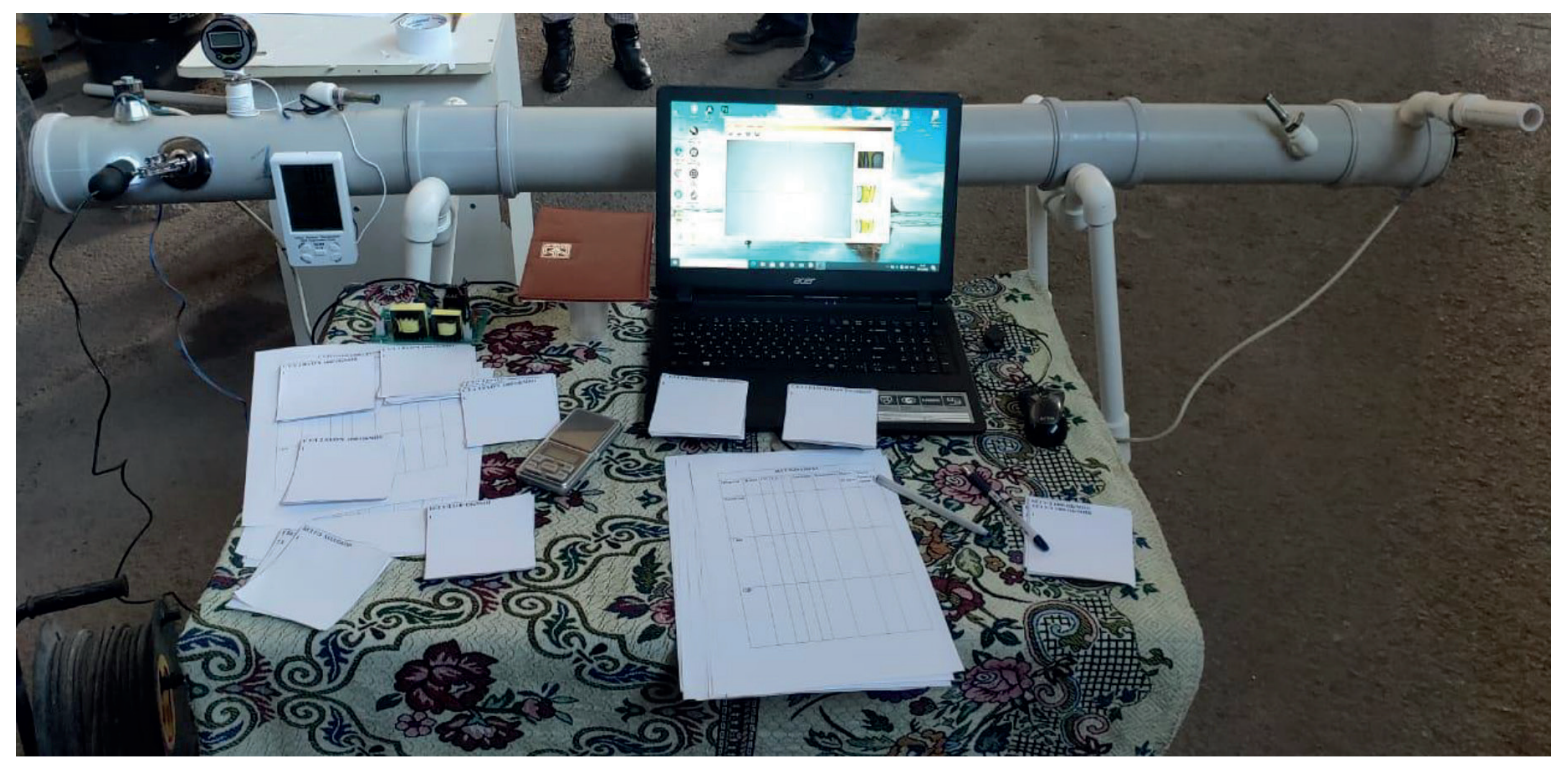

Figure 3 Experimental ultrasonic muffler

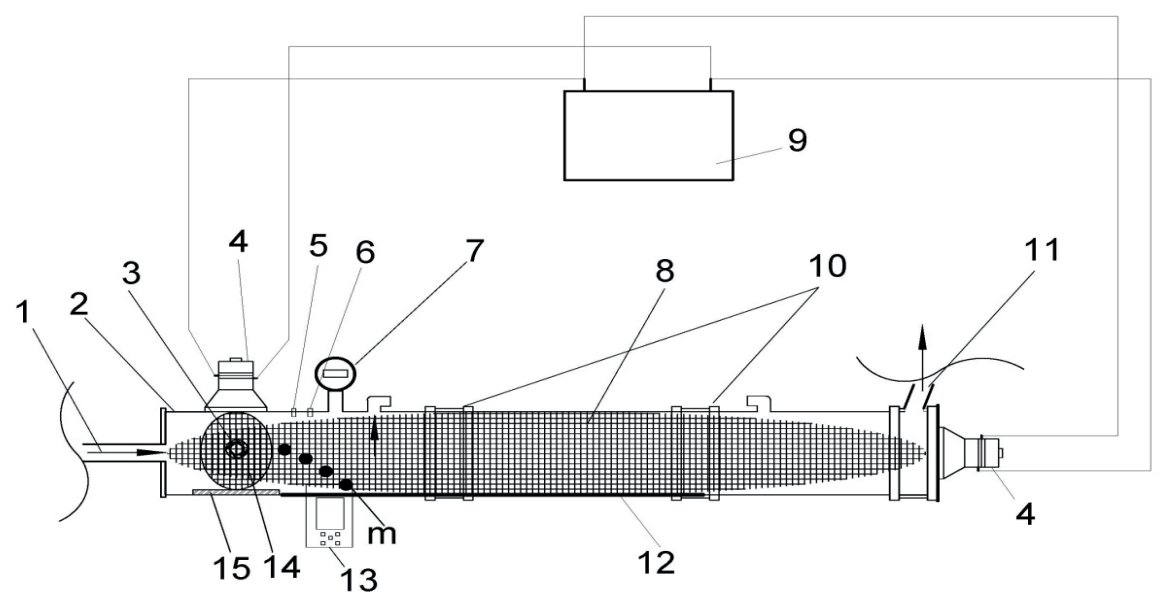

1- inlet pipe; 2 - the housing of the ultrasonic muffler; 3 - electron microscope MIKMED 2.0; 4 - ultrasonic emitter; 5 - temperature sensor; 6 - moisture meter; 7 - electronic pressure gauge;

8 - the area of influence of longitudinal ultrasonic waves; 9 - ultrasonic generator; 10 - pipe coupling;

11 - outlet branch pipe; 12 - the place of the soot collection; 13 - thermometer-hygrometer; 14 - the area of influence of the transverse ultrasonic waves; 15 - reflector

Figure 4 Diagram of a universal ultrasonic muffler

\section{Experiment}

The purpose of the experiment is to obtain dependencies that determine the parameters of coagulation: the mass of soot, the coagulation coefficient and its rate to achieve the set goals, a full-scale experiment was carried out on a developed laboratory full-size stand (Figures 3, 4 and 5). The exhaust gas contains toxins: $\mathrm{CO}$ (carbon monoxide) and $\mathrm{CH}$ (hydrocarbon). During the experiment, at the first stage, the degree of purification of the exhaust gas from hydrocarbon $(\mathrm{CH})$ and carbon monoxide $(\mathrm{CO})$ was determined. At the second stage, the graphs of the dependence of the mass of deposited soot on the length of the muffler L were established. During the processing, the coagulation coefficient was calculated.

The diagram of the experimental ultrasonic muffler is shown in Figure 4.

The experimental ultrasonic muffler (Figures 4 and 5) consists of a polypropylene pipe with a diameter of $110 \mathrm{~mm}$ and a length of $3 \mathrm{~m}$. The ultrasonic equipment is installed in the muffler housing, consisting of an ultrasonic generator - 9 , two ultrasonic emitters - 4 and a reflector of ultrasonic waves - 15; digital USB microscope Mikmed 2.0 - 3 with a magnification ratio of 20 to $200 \mathrm{x}$ with the possibility of photo and video recording at a resolution of $1920 \times 1080$ pixels; temperature sensor -5 and hygrometer -6 , transmitting information to the thermometer-hygrometer - 13; electronic pressure gauge - 7; reflector - 15 . 


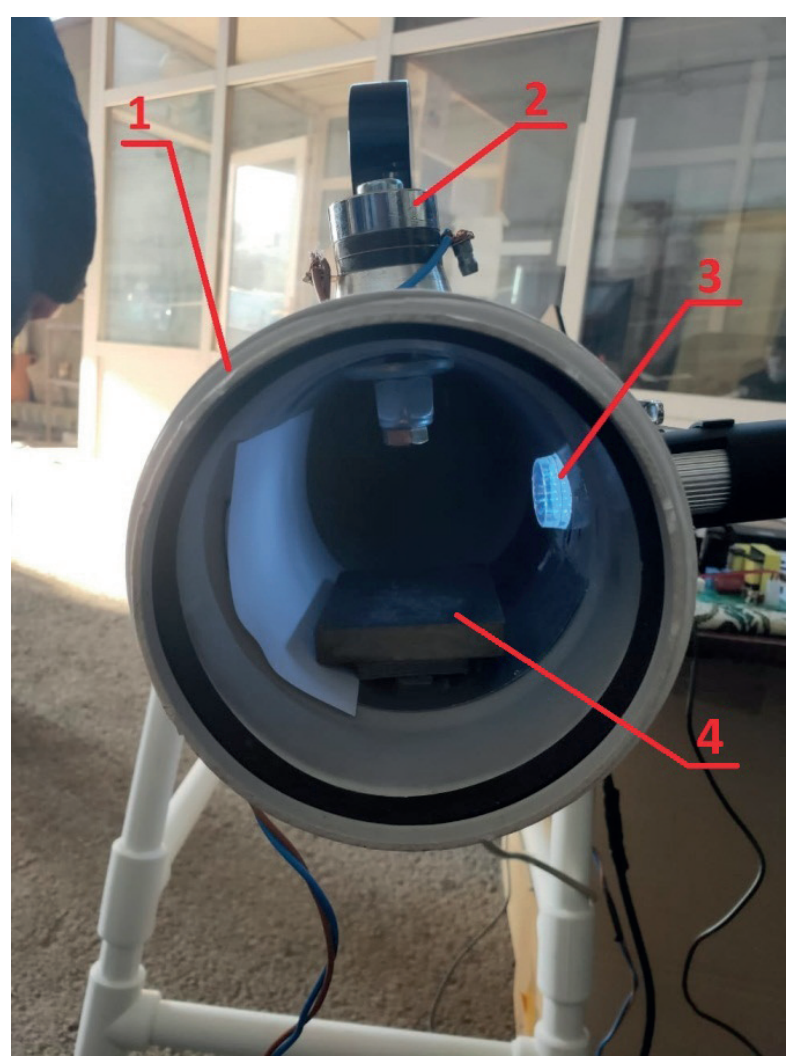

1- ultrasonic muffler body, 2 - ultrasonic emitter, 3 - digital USB microscope, 4 - reflector

Figure 5 Internal design of an ultrasonic muffler

To determine the qualitative and quantitative composition of the exhaust gas mixture, a Meta Autotest 01.03 gas analyzer was used. An ultrasonic generator manufactured by TOCOOL (China) was used. Input voltage AC $220 \mathrm{~V}$, with emitter power - $50 \mathrm{~W}$, ultrasonic wave generation frequency $-40 \mathrm{kHz}$. To investigate the internal processes of the ultrasonic muffler, a Mikmed 2.0 USB microscope was installed in the housing, designed for quality control and testing of industrial objects.

The experimental research was carried out as follows:

- tests were carried out without and with turning on the ultrasonic equipment for 5 minutes each;

- the lower part of the device along a semicircle was lined with five numbered sheets of paper $10 \times 10 \mathrm{~cm}$ in size, with a total length of $50 \mathrm{~cm}$, the mass of which was determined before and after testing with high-precision jewelry scales "MH-500";

- the research was carried out at an idle speed of the engine crankshaft (1000 rpm) and at $1250 \mathrm{rpm}$. Applied is Volkswagen Passat B3 1991, with engine capacity $1800 \mathrm{cc}$. see, fuel injection - mono-Motronic, engine power $90 \mathrm{~kW}$, fuel grade - AI-92 gasoline.

The spent exhaust gas was supplied to the ultrasonic muffler through the inlet pipe 1 at a pressure that depends on the crankshaft speed. In the muffler, with the ultrasonic equipment turned on, the ultrasonic waves were applied to the exhaust gas in the transverse and longitudinal directions. In the sections, the ultrasonic intensification of coagulation processes and cleaning of exhaust gases took place due to the sedimentation of enlarged particles of exhaust gas at the place where the soot -12 was collected. The cleaned exhaust gas was discharged through the outlet pipe -11 .

During the operation of the ultrasonic muffler, the readings of the Meta Autotest 01.03 gas analyzer connected to the outlet pipe were taken. In addition the readings of the manometer, thermo-hygrometer were recorded and photos and video were recorded inside the ultrasonic muffler using a Mikmed 2.0 digital microscope, with the possibility of magnification from 20 to $200 \mathrm{x}$, at a maximum resolution of $1920 \times$ 1080 pixels (photos are not shown due to the lack of clear images during the transfer). The gas analyzer data indicated the concentration of harmful substances (hydrocarbon $(\mathrm{CH})$ and carbon monoxide $(\mathrm{CO})$ contained in the exhaust gas. The data are presented in Tables 1 , 2 and in the diagrams in Figures 6 and 7. After each test, the numbered paper with settled soot particles was carefully removed and weighed again. The net weight of the settled soot was determined by subtracting the weight of the paper from the weight of the carbon black paper. The position of the paper sheets in the ultrasonic muffler was used to calculate the settling distance of soot particles (Tables $3-6$ ). 
Table 1 Concentration of $\mathrm{CH}$ and $\mathrm{CO}$ at $1000 \mathrm{rpm}$

\begin{tabular}{lcc}
\hline ultrasonic muffler operation & CH (ppm) & CO (\%) \\
\hline without ultrasound & 50 & 1.2 \\
with ultrasound (1 transverse emitter) & 31 & 1.2 \\
with ultrasound (2 emitters) & 29 & 1.6 \\
with ultrasound (1 longitudinal emitter) & 27 & 1.2 \\
\hline
\end{tabular}

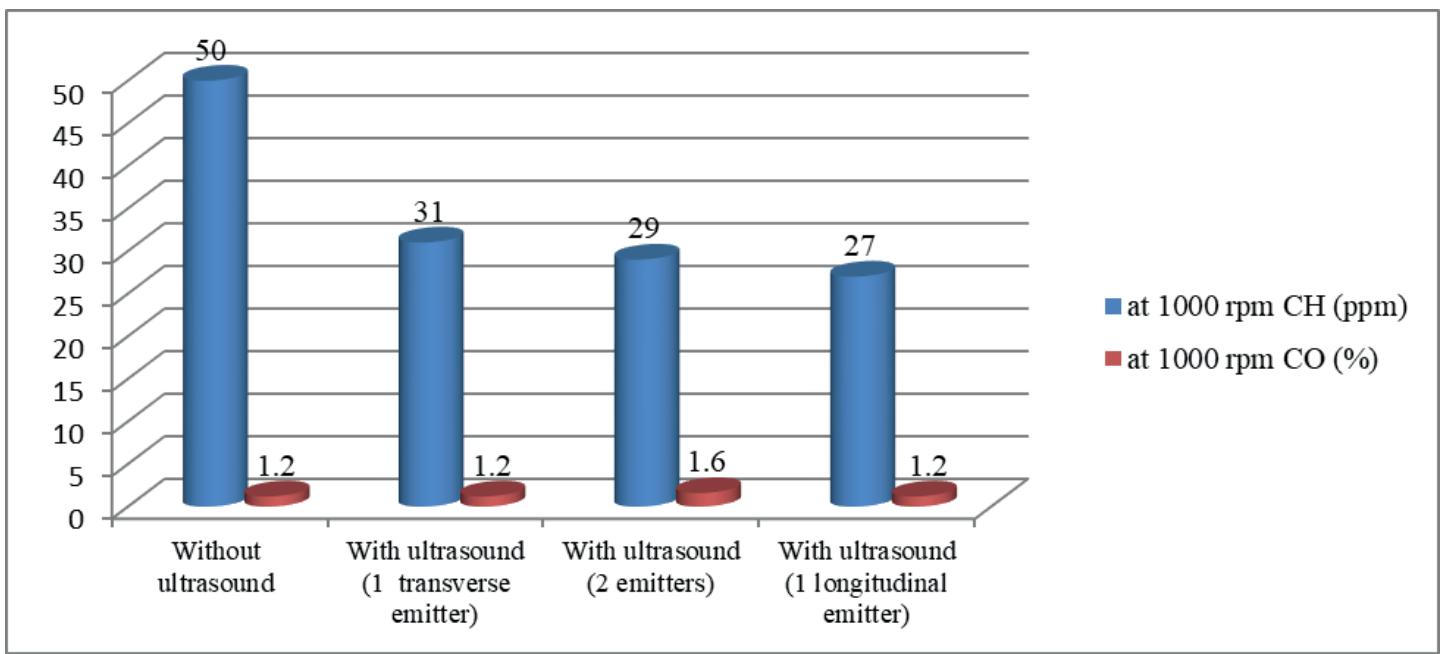

Figure 6 Diagram of the $\mathrm{CH}$ and $\mathrm{CO}$ content in the exhaust gas at 1000 rpm of a crankshaft

Table 2 Concentration of $\mathrm{CH}$ and $\mathrm{CO}$ at $1250 \mathrm{rpm}$

\begin{tabular}{lcc}
\hline ultrasonic muffler operation & $\mathrm{CH}(\mathrm{ppm})$ & $\mathrm{CO}(\%)$ \\
\hline without ultrasound & 27 & 0.62 \\
with ultrasound (1 transverse emitter) & 14 & 0.76 \\
with ultrasound (2 emitters) & 12 & 0.9 \\
\hline
\end{tabular}

\section{Experiment design, results and data processing}

Previously, 5 repeated experiments were carried out. The coefficient of variation $\mathrm{W}$ is determined:

$W=\frac{\sigma}{\bar{X}}$,

where:

$\sigma$ - the standard deviation,

$\bar{X}$-the arithmetic mean of the results of five measurements (experiments).

The coefficient of variation was 0.07 .

The minimum permissible value of repeated experiments with a confidence level of $90 \%$ and a limiting relative experimental error of $9 \%$ was determined [10].

The number of repeated experiments was determined from the expression:

$n=\left(\frac{t_{s} W}{\varepsilon}\right)^{2}=\left(\frac{2.13 \times 0.07}{0.09}\right)=2.66 \approx 3$,

where:

$t_{s}$ - Student's coefficient, selected taking into account a given confidence level, from a specially compiled table of the distribution of the Student's values; $\varepsilon$ - limiting relative error of the experiment [11].

It was found that the number of repeated experiments is 3 .

At the first stage of the experiment, the validity of the hypothesis about the possibility of cleaning the exhaust gases by ultrasound in a car muffler was proved. Tables 1 and 2 and diagrams (Figures 6 and 7) show the concentration of $\mathrm{CH}$ and $\mathrm{CO}$ in the muffler.

The longitudinal radiator is more efficient than the transverse one since the gas pressure from the collector and the pressure of sound waves are directed against each other, in this regard, the friction of particles increases, depending on the difference in velocities $\Delta$ $\mathrm{V}$ and dynamic viscosity $\eta$.

An increase in the number of revolutions increases the mass of deposited soot, which explains the difference in the diagrams shown in Figures 6 and 7. The bottom line is that with an increase in the mass of soot, the mass of the exhaust gas increases proportionally and the greater the number of engine revolutions. The hypothesis about the possibility of reducing the 


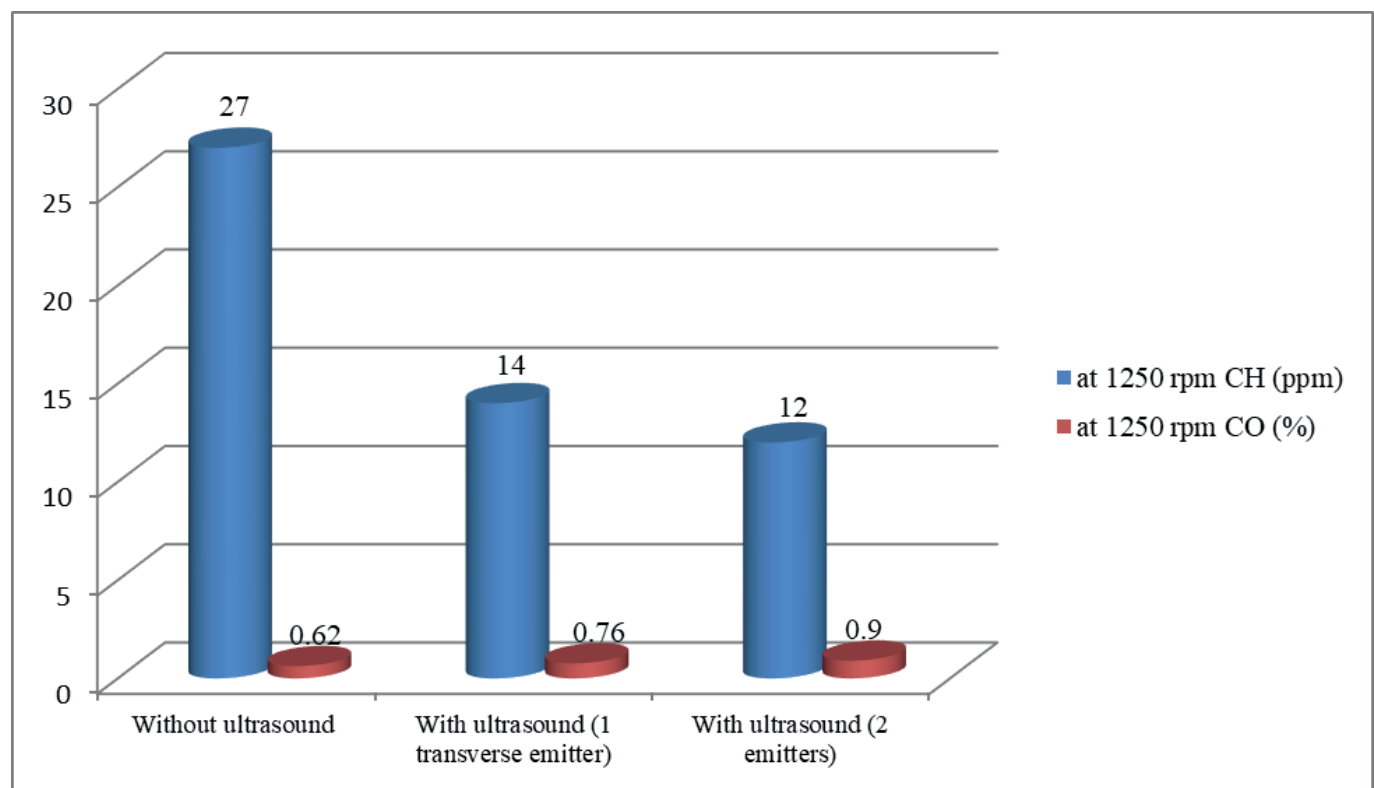

Figure 7 Diagram of the $\mathrm{CH}$ and $\mathrm{CO}$ content in the exhaust gas at $1250 \mathrm{rpm}$ of a crankshaft

Table 3 The mass of the settled soot at 1000 rpm without ultrasound

\begin{tabular}{ccccccc}
\hline \multicolumn{2}{c}{ time } & \multicolumn{3}{c}{$\begin{array}{c}\text { thermometer } \\
\text { reading }\end{array}$} & \multicolumn{3}{c}{ soot mass determination } \\
\hline $\begin{array}{c}\text { total time } \\
(\mathrm{min})\end{array}$ & minute & $\mathrm{t}\left({ }^{\circ} \mathrm{C}\right)$ & distance $(\mathrm{mm})$ & $\begin{array}{c}\text { paper } \\
\text { weight }(\mathrm{g})\end{array}$ & $\begin{array}{c}\text { paper weight } \\
\text { with soot }(\mathrm{g})\end{array}$ & net weight of settled soot (g) \\
\hline & 1 & 10.5 & 100 & 0.75 & 1.00 & 0.25 \\
& 2 & 11.7 & 200 & 0.84 & 1.00 & 0.16 \\
5 & 3 & 12.3 & 300 & 0.84 & 0.95 & 0.11 \\
& 4 & 18.5 & 400 & 0.87 & 0.92 & 0.05 \\
\hline
\end{tabular}

Table 4 The mass of the settled soot at 1000 rpm with ultrasound (2 emitters)

\begin{tabular}{|c|c|c|c|c|c|c|}
\hline \multicolumn{2}{|c|}{ time } & \multirow{2}{*}{$\begin{array}{c}\text { thermometer } \\
\text { reading } \\
\mathrm{t}\left({ }^{\circ} \mathrm{C}\right)\end{array}$} & \multicolumn{4}{|c|}{ soot mass determination } \\
\hline $\begin{array}{l}\text { total } \\
\text { time } \\
(\mathrm{min})\end{array}$ & minute & & distance $(\mathrm{mm})$ & $\begin{array}{c}\text { paper } \\
\text { weight }(\mathrm{g})\end{array}$ & $\begin{array}{l}\text { paper weight } \\
\text { with soot }(\mathrm{g})\end{array}$ & net weight of settled soot $(\mathrm{g})$ \\
\hline \multirow{5}{*}{5} & 1 & 16.1 & 100 & 0.74 & 1.08 & 0.34 \\
\hline & 2 & 18.8 & 200 & 0.77 & 0.98 & 0.21 \\
\hline & 3 & 23.0 & 300 & 0.74 & 0.88 & 0.14 \\
\hline & 4 & 26.3 & 400 & 0.75 & 1.20 & 0.45 \\
\hline & 5 & 29.2 & 500 & 0.72 & 1.10 & 0.38 \\
\hline
\end{tabular}

Table 5 The mass of the settled soot at 1000 rpm with ultrasound (1 transverse emitter)

\begin{tabular}{|c|c|c|c|c|c|c|}
\hline \multicolumn{2}{|c|}{ time } & \multirow{2}{*}{$\begin{array}{c}\text { thermometer } \\
\text { reading } \\
\mathrm{t}\left({ }^{\circ} \mathrm{C}\right)\end{array}$} & \multicolumn{4}{|c|}{ soot mass determination } \\
\hline $\begin{array}{c}\text { total } \\
\text { time } \\
\text { (min) }\end{array}$ & minute & & distance $(\mathrm{mm})$ & $\begin{array}{c}\text { paper } \\
\text { weight }(\mathrm{g})\end{array}$ & $\begin{array}{l}\text { paper weight } \\
\text { with soot }(g)\end{array}$ & net weight of settled soot (g) \\
\hline \multirow{5}{*}{5} & 1 & 15.8 & 100 & 0.88 & 1.21 & 0.33 \\
\hline & 2 & 19.3 & 200 & 0.88 & 1.15 & 0.27 \\
\hline & 3 & 25.4 & 300 & 0.87 & 1.07 & 0.20 \\
\hline & 4 & 27.8 & 400 & 0.86 & 1.02 & 0.16 \\
\hline & 5 & 30.7 & 500 & 0.88 & 1.01 & 0.13 \\
\hline
\end{tabular}


Table 6 The mass of the settled soot at $1000 \mathrm{rpm}$ with ultrasound (1 longitudinal emitter)

\begin{tabular}{|c|c|c|c|c|c|c|}
\hline \multicolumn{2}{|c|}{ time } & \multirow{2}{*}{$\begin{array}{c}\text { thermometer } \\
\text { reading }\end{array}$} & \multicolumn{4}{|c|}{ soot mass determination } \\
\hline $\begin{array}{l}\text { total } \\
\text { time } \\
\text { (min) }\end{array}$ & minute & & distance $(\mathrm{mm})$ & $\begin{array}{c}\text { paper } \\
\text { weight }(\mathrm{g})\end{array}$ & $\begin{array}{l}\text { paper weight } \\
\text { with soot }(\mathrm{g})\end{array}$ & net weight of settled soot (g) \\
\hline \multirow{5}{*}{5} & 1 & 18.6 & 100 & 0.78 & 1.46 & 0.37 \\
\hline & 2 & 20.6 & 200 & 0.76 & 0.95 & 0.19 \\
\hline & 3 & 23.2 & 300 & 0.79 & 0.91 & 0.12 \\
\hline & 4 & 25.3 & 400 & 0.80 & 1.15 & 0.35 \\
\hline & 5 & 27.2 & 500 & 0.78 & 1.04 & 0.26 \\
\hline
\end{tabular}

Table 7 Comparison of the mass of settled soot at 1000 rpm.

\begin{tabular}{ccccc}
\hline distance $(\mathrm{mm})$ & without ultrasound & $\begin{array}{c}\text { with ultrasound } \\
(2 \text { emitters })\end{array}$ & $\begin{array}{c}\text { with ultrasound } \\
(1 \text { transverse emitter })\end{array}$ & $\begin{array}{c}\text { with ultrasound } \\
\text { (1 longitudinal emitter) }\end{array}$ \\
\hline 100 & 0.25 & 0.34 & 0.33 & 0.37 \\
200 & 0.16 & 0.21 & 0.27 & 0.19 \\
300 & 0.11 & 0.14 & 0.2 & 0.12 \\
400 & 0.05 & 0.45 & 0.16 & 0.35 \\
500 & 0.1 & 0.38 & 0.13 & 0.26 \\
\hline$\Sigma$ & 0.67 & 1.52 & 1.09 & 1.29 \\
\hline
\end{tabular}

Table 8 Mass of settled soot at 1250 rpm without ultrasound

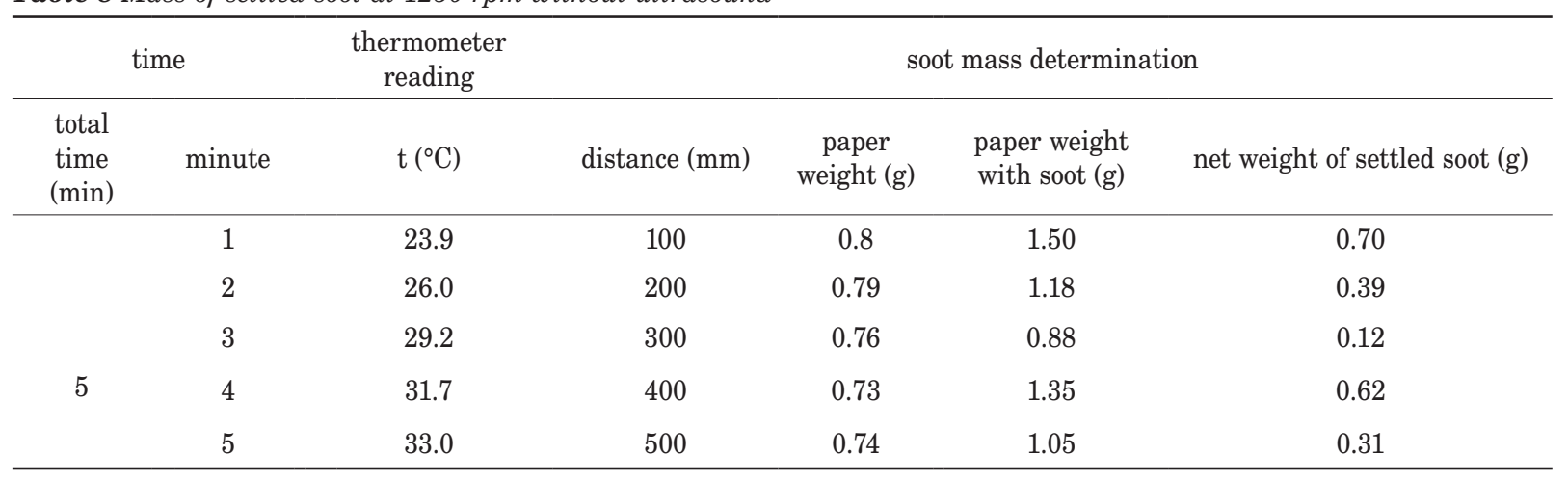

Table 9 Mass of settled soot at 1250 rpm with ultrasound (2 emitters)

\begin{tabular}{|c|c|c|c|c|c|c|}
\hline \multicolumn{2}{|c|}{ time } & \multirow{2}{*}{$\begin{array}{l}\text { thermometer } \\
\text { reading } \\
t\left({ }^{\circ} \mathrm{C}\right)\end{array}$} & \multicolumn{4}{|c|}{ soot mass determination } \\
\hline $\begin{array}{l}\text { total time } \\
\quad(\min )\end{array}$ & minute & & distance $(\mathrm{mm})$ & $\begin{array}{c}\text { paper } \\
\text { weight }(\mathrm{g})\end{array}$ & $\begin{array}{l}\text { paper weight } \\
\text { with soot (g) }\end{array}$ & net weight of settled soot $(\mathrm{g})$ \\
\hline \multirow{5}{*}{5} & 1 & 26.4 & 100 & 0.85 & 1.92 & 1.07 \\
\hline & 2 & 28.8 & 200 & 0.77 & 1.86 & 1.09 \\
\hline & 3 & 31.5 & 300 & 0.76 & 1.51 & 0.75 \\
\hline & 4 & 33.3 & 400 & 0.78 & 1.62 & 0.84 \\
\hline & 5 & 35.4 & 500 & 0.79 & 1.49 & 0.70 \\
\hline
\end{tabular}

toxicity of exhaust gases in the ultrasonic muffler was confirmed. Moreover, the most effective cleaning of the exhaust gas of the hydrocarbon is when the emitter is operating in the longitudinal direction of gas movement since in this case the heaviest gas particles immediately begin to settle.
At the second stage of the experiment, the dependence of the settled soot mass on the sedimentation length L was investigated. Tables 3 to 11 give examples of the experimental results' recordings.

Tables 3, 4, 5 and 6 show the masses of settled soot without ultrasound, with two emitters, transverse and 
Table 10 Mass of settled soot at $1250 \mathrm{rpm}$ with ultrasound (1 transverse emitter)

\begin{tabular}{|c|c|c|c|c|c|c|}
\hline \multicolumn{2}{|c|}{ time } & \multirow{2}{*}{$\begin{array}{c}\text { thermometer } \\
\text { reading } \\
\mathrm{t}\left({ }^{\circ} \mathrm{C}\right)\end{array}$} & \multicolumn{4}{|c|}{ soot mass determination } \\
\hline $\begin{array}{l}\text { total time } \\
\quad(\min )\end{array}$ & minute & & distance $(\mathrm{mm})$ & $\begin{array}{c}\text { paper } \\
\text { weight }(\mathrm{g})\end{array}$ & $\begin{array}{l}\text { paper weight } \\
\text { with soot (g) }\end{array}$ & net weight of settled soot $(\mathrm{g})$ \\
\hline \multirow{5}{*}{5} & 1 & 24.7 & 100 & 0.92 & 2.28 & 0.85 \\
\hline & 2 & 27.3 & 200 & 0.88 & 1.79 & 0.91 \\
\hline & 3 & 29.4 & 300 & 0.86 & 1.78 & 0.92 \\
\hline & 4 & 33.1 & 400 & 0.89 & 1.87 & 0.98 \\
\hline & 5 & 38.0 & 500 & 0.96 & 1.63 & 0.67 \\
\hline
\end{tabular}

Table 11 Comparison of the mass of settled soot at $1250 \mathrm{rpm}$.

\begin{tabular}{cccc}
\hline distance $(\mathrm{mm})$ & without ultrasound & with ultrasound (2 emitters) & $\begin{array}{c}\text { with ultrasound } \\
(1 \text { transverse emitter) }\end{array}$ \\
\hline 100 & 0.70 & 1.07 & 0.85 \\
200 & 0.39 & 1.09 & 0.91 \\
300 & 0.12 & 0.75 & 0.92 \\
400 & 0.62 & 0.84 & 0.98 \\
500 & 0.31 & 0.70 & 0.67 \\
\hline$\Sigma$ & 2.14 & 4.45 & 4.33 \\
\hline
\end{tabular}

longitudinal emitters at $1000 \mathrm{rpm}$. Determination of the net mass of the settled soot was made by subtracting the mass of the paper from the mass of the paper with soot. The results are summarized in Table 7. From that table follows that the operation of two emitters is the most effective and the longitudinal emitter is more conducive to large gas coagulation. Thus, the gas purification of the $\mathrm{CH}$ is the most effective with a longitudinal emitter, this is explained by the long path of the particles through the muffler and hence the long time of exposure to ultrasound. A change in the carbon monoxide (CO) reading indicates an increase in concentration due to exposure to ultrasonic waves. In this case, the length $\mathrm{L}$, at which the $\mathrm{CO}$ molecules were to be deposited, is insufficient. The volatility of $\mathrm{CO}$ is higher than of the $\mathrm{CH}$.

Tables 8,9 and 10 show the gas coagulation data at $1250 \mathrm{rpm}$ and Table 11 summarizes. Determination of the net mass of the settled soot was made by subtracting the mass of the paper from the mass of the paper with soot.

The conclusions from Table 11 are the same as before. However, it was found that the mass of coagulation increases significantly (2-2.5 times) with an increase in the engine speed. Figures 8 and 9 show experimental graphs of the dependence of the settled soot mass on the muffler's length $\mathrm{L}$.

As follows from the graphs, there is a local maximum in the soot deposition at a distance of $400 \mathrm{~mm}$ from the exhaust pipe. This is quantitatively true for the stand, but the qualitative relationship will also be true for the polypropylene mufflers. Moreover, the highest deposition is provided by the two emitters and the longitudinal emitter is more efficient than the transverse one.
According to the tables, the following were determined:

- mass of the soot settled during the operation without ultrasound $m_{0}$, this mass corresponds to orthokinetic coagulation;

- the total mass of the soot under the action of ultrasound $m_{u}$;

- then the mass without the action of ultrasound $m_{0}$ was subtracted from the total mass $m_{u}$ and the mass of the hydrodynamic coagulation soot $m_{g}$ was determined [12]:

$m_{u}-m_{0}=m_{s}$

Tables 12 and 13 show the size data for orthokinetic and hydrodynamic coagulation. The data obtained made it possible to quantitatively determine the weight of hydrodynamic coagulation.

The coefficient of hydrodynamic coagulation was set in relation to the mass of orthokinetic coagulation, since the latter always takes place:

$K_{g}=\frac{\sum m_{g}}{\sum m_{0}}$.

The calculated values of the hydrodynamic coagulation coefficient are shown in Table 14.

According to the results of calculations from Table 14 , it follows that hydrodynamic coagulation is the most effective under the influence of a longitudinal emitter, the maximum results were shown by the installation option with 2 emitters, since the intensity of ultrasound exposure was 2 times higher.

During the experiment, photo and video recordings were made inside the ultrasonic muffler using a Mikmed 


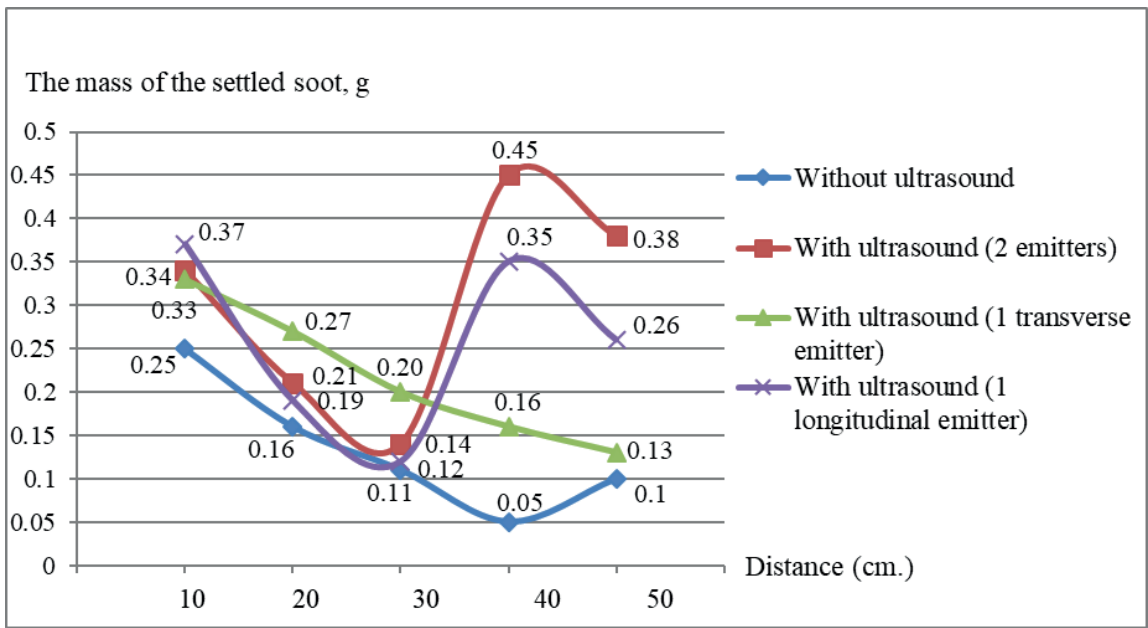

Figure 8 Graph of dependence of the settled soot mass on the settling distance at 1000 rpm of the crankshaft

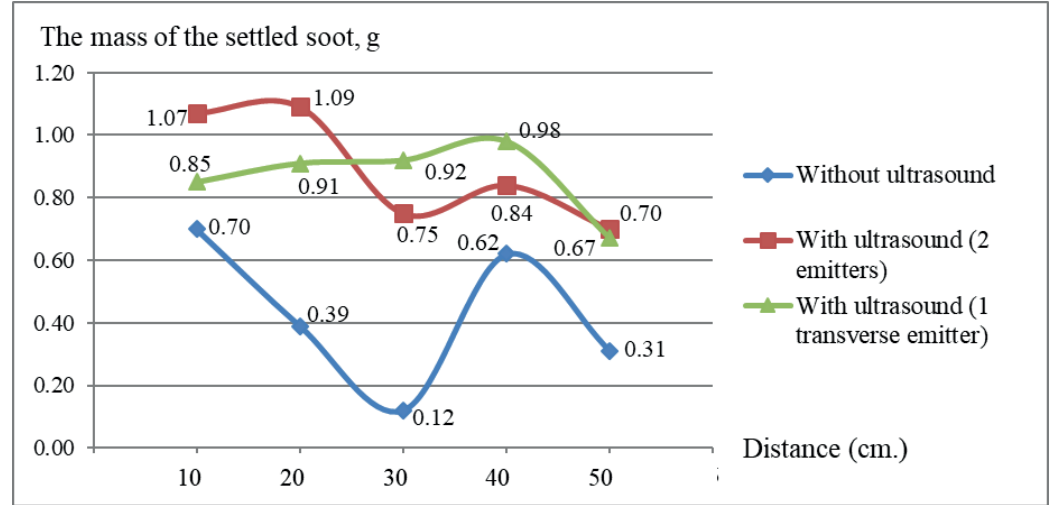

Figure 9 Graph of dependence of the settled soot mass on the settling distance at 1250 rpm of the crankshaft

Table 12 Mass of soot from hydrodynamic coagulation at 1000/1250 rpm under the influence of 2 ultrasonic emitters

\begin{tabular}{|c|c|c|c|}
\hline \multicolumn{4}{|c|}{ determination of the mass of soot } \\
\hline $\begin{array}{l}\text { distance } \\
(\mathrm{mm})\end{array}$ & $\begin{array}{l}\text { the mass of settled soot } \\
\text { under the action } \\
\text { ultrasound, } m_{u}(\mathrm{~g})\end{array}$ & $\begin{array}{c}\text { mass of settled soot without } \\
\text { ultrasound (g) } \\
\text { (action of orthokinetic coagulation), } m_{0}\end{array}$ & $\begin{array}{l}\text { the mass of settled soot from the action } \\
\text { of hydrodynamic coagulation, } m_{g}(\mathrm{~g})\end{array}$ \\
\hline 100 & $0.34 / 1.07$ & $0.25 / 0.70$ & $0.9 / 0.37$ \\
\hline 200 & $0.21 / 1.09$ & $0.16 / 0.39$ & $0.05 / 0.7$ \\
\hline 300 & $0.14 / 0.75$ & $0.11 / 0.12$ & $0.03 / 0.63$ \\
\hline 400 & $0.45 / 0.84$ & $0.05 / 0.62$ & $0.4 / 0.22$ \\
\hline 500 & $0.38 / 0.70$ & $0.10 / 0.31$ & $0.28 / 0.39$ \\
\hline
\end{tabular}

Table 13 Mass of soot from hydrodynamic coagulation at 1000/1250 rpm. under the influence of one transverse ultrasonic emitter

\begin{tabular}{|c|c|c|c|}
\hline \multicolumn{4}{|c|}{ determination of the mass of soot } \\
\hline $\begin{array}{l}\text { distance } \\
(\mathrm{mm})\end{array}$ & $\begin{array}{l}\text { the mass of settled soot } \\
\text { under the action } \\
\text { ultrasound, } m_{u}(\mathrm{~g})\end{array}$ & $\begin{array}{c}\text { mass of settled soot without } \\
\text { ultrasound (g) } \\
\text { (action of orthokinetic coagulation), } m_{0}\end{array}$ & $\begin{array}{l}\text { the mass of settled soot from the action } \\
\text { of hydrodynamic coagulation, } m_{g}(\mathrm{~g})\end{array}$ \\
\hline 100 & $0.33 / 0.85$ & $0.25 / 0.70$ & $0.08 / 0.15$ \\
\hline 200 & $0.27 / 0.91$ & $0.16 / 0.39$ & $0.11 / 0.52$ \\
\hline 300 & $0.20 / 0.92$ & $0.11 / 0.12$ & $0.09 / 0.8$ \\
\hline 400 & $0.16 / 0.98$ & $0.05 / 0.62$ & $0.11 / 0.36$ \\
\hline 500 & $0.13 / 0.67$ & $0.10 / 0.31$ & $0.03 / 0.36$ \\
\hline
\end{tabular}


Table 14 The coefficient of hydrodynamic coagulation

\begin{tabular}{cccc}
\hline & & coagulation coefficient value, $\mathrm{s}^{-1}$ & \\
\cline { 2 - 4 }$(\mathrm{rpm})$ & $\begin{array}{c}\text { under the influence of ultrasound } \\
(2 \text { emitters })\end{array}$ & $\begin{array}{c}\text { under the influence of ultrasound } \\
(1 \text { transverse emitter })\end{array}$ & $\begin{array}{c}\text { under the influence of } \\
\text { ultrasound } \\
(1 \text { longitudinal emitter })\end{array}$ \\
\hline $1000 / 1250$ & $1.27 / 1.08$ & $0.62 / 1.26$ & 0.93 \\
\hline
\end{tabular}

2.0 digital microscope with the ability to magnify from 20 to $200 \mathrm{x}$ at a maximum resolution of $1920 \times 1080$ pixels without ultrasound and with ultrasound.

\section{Conclusions}

In order to reduce the transport emissions and purify the exhaust gases from vehicles, at minimum costs and maximum efficiency of this system, it is necessary to use the ultrasonic cleaning of exhaust gases, since the ultrasonic effect on aerosols makes it possible to enhance the phenomenon of the exhaust gas particles coagulation and contributes to their settling inside the muffler body in the form of carbon deposits. The proposed method of cleaning the exhaust gases, which is a result of the experiment, has shown its effectiveness and applicability in the field of transport.

The effectiveness of application of ultrasonic action on the exhaust gas of motor vehicles was proved in the course of the experiment and has a promising development in this direction of cleaning the aerosols of the harmful impurities by the proposed method. According to the results of the experiment, the concentration of the hydrocarbon decreased by more than twice - at $1000 \mathrm{rpm}$ of the engine crankshaft from $50 \mathrm{ppm} / \mathrm{min}$ to $27 \mathrm{ppm} / \mathrm{min}$ and at $1250 \mathrm{rpm}$ from 27 $\mathrm{ppm} / \mathrm{min}$ to $12 \mathrm{ppm} / \mathrm{min}$.

The total mass of the settled soot in the experimental device under the action of ultrasound exceeds the mass of the settled soot without ultrasound by more than 1.5 times. Hydrodynamic coagulation is superior to the orthokinetic cleaning in terms of efficiency. The longitudinal radiator is more efficient than the transverse radiator in the process of cleaning the exhaust gas from the hydrocarbon, since the coagulation takes place at a greater distance. In this experiment, the longitudinal emitter showed the maximum result for cleaning of the $\mathrm{CH}$ and in the process of the soot particles settling, a variant of an installation with two emitters. This fact indicates the need to use the two emitters in one design, longitudinal and transverse.

The article proves the hypothesis of reducing the harmful emissions through use of the ultrasonic mufflers, the design of which is proposed in the patent [6].

The conducted experimental studies are the basis for creating an engineering calculation method during the development of experimental samples of ultrasonic mufflers [13-14].

\section{References}

[1] KORABLEV, R. A., BELOKUROV, V. P., ZELIKOV, V. A., LIKHACHEV, D. V., RAZGONYAEVA, V. V., BOYKO, N. I. Environmental safety of vehicles. Voronezh, 2011.

[2] KADYROVA, I. A., MINDUBAEVA, F. A., GRJIBOVSKI, A. M. Prediction of outcomes after stroke: a systematic review (in Russian). Human Ecology [online]. 2015, 2015(10), p. 55-64. ISSN 1728-0869. Available from: https://doi.org/10.33396/1728-0869-2015-10-55-64

[3] RIERA-FRANCO DE SARABIA, E., ELVIRA-SEGURA, L., GONZALEZ-GOMEZ, I., RODRIGUEZ-MAROTO, J. J., MUNOZ-BUENO, R., DORRONSORO-AREAL, J. L. Investigation of the influence of humidity on the ultrasonic agglomeration of submicron particles in diesel exhausts. Ultrasonics [online]. 2003, 41(4), p. 277-281. ISSN 0041-624X. Available from: https://doi.org/10.1016/S0041-624X(02)00452-3

[4] Patent RU 2364736 C2 Method of cleaning exhaust gas from particles. Declared 12/20/2008, publ. 08/20/2009 Bul. No. 23.

[5] Patent RU 2373409 C2 Device for cleaning automobile exhaust gases from particles. Declared 06/10/2009, publ. 11/20/2009 Bul. No. 32 .

[6] Patent RK No. 3194. Device for ultrasonic cleaning of exhaust gases. Declared 12/20/2017, publ. 10/02/2018.

[7] BALDEV, R., RAJENDRAN, V., PALANICHAMI, P. Applications of ultrasound. Moscow: Technosphere, 2006. ISBN 5-94836-088-1.

[8] DONG, S., LIPKENS, B., CAMERON, T. V. The effects of orthokinetic collision, acoustic wake and gravity on acoustic agglomeration of polydisperse aerosols. Journal of Aerosol Science [online]. 2006, 37(4), p. 540-553. ISSN 0021-8502. Available from: https://doi.org/10.1016/j.jaerosci.2005.05.008

[9] BERGMAN, L. Ultrasound and its application in science and technology. Moscow: Publishing house of foreign literature, 1957. 
[10] SHEROV, K. T., KHODZIBERGENOV, D. T., IBRAGIMOVA, Z. A., KHODZIBERGENOVA, U. D., ABDUKARIMOV, A., ESIRKEPOV, A. Some aspects of software in cutting tools designing and testing. Russian Engineering Research [online]. 2019, 39(9), p. 772-775. ISSN 1068-798X. Available from: https://doi.org/10.3103/ S1068798X19090090

[11] YESSIRKEPOVA, A. B., SHEROV, K. T., MIKHAILOV, V. F., BUZAUOVA, T. M., MAZDUBAY, A. V., TASKARINA, A. Z. Research of ways of connecting reinforced bars in the production of reinforced concrete products. Journal of Applied Engineering Science [online]. 2020, 18(3), p. 372-377. ISSN 1451-4117, eISSN 18213197. Available from: https://doi.org/10.5937/jaes18-24319

[12] IBATOV, M. K., KADYROV, A. S., PAK, I. A., KADYROVA, I. A., ASKAROV, B. S. Results of experimental studies of the operation of capacitive equipment for ultrasonic cleaning of exhaust gases of vehicles. Ugol [online]. 2020, 2, p. 73-78. ISSN 0041-5790, eISSN 2412-8333. Available from: https://doi.org/10.18796 / 0041-5790-2020-2-73-78

[13] KADYROV, A., GANYUKOV, A., PAK, I., SULEYEV, B., BALABEKOVA, K. Theoretical and experimental study of operation of the tank equipment for ultrasonic purification of the internal combustion engine exhaust gases. Communications - Scientific Letters of the University of Zilina [online]. 2021, 23(3), p. B219-B226. ISSN 1335-4205, eISSN 2585-7878. Available from: https://doi.org/10.26552/com.C.2021.3.B219-B226

[14] KADYROV A., ZHUNUSBEKOVA Z., GANYUKOV A., KADYROVA I., KUKESHEVA A. General characteristics for loading the working elements of drilling and milling machines when moving in the clay solution. Communications - Scientific Letters of the University of Zilina [online]. 2021, 23(2), p. B97-B105. ISSN 1335-4205, eISSN 2585-7878. Available from: https://doi.org/10.26552/com.C.2021.2.B97-B105 